\title{
THE ANALYSIS OF ENGLISH LECTURERS' CLASSROOM-BASED READING ASSESSMENTS TO IMPROVE STUDENTS' READING COMPREHENSION
}

\author{
Yanuarti Apsari \\ yanuar.apsari1@gmail.com
}

Acep Haryudin

haryacep@gmail.com

STKIP SILIWANGI BANDUNG

\begin{abstract}
The objectives of this research are to identify techniques that the lecturers use in assessing reading comprehension and to find the way English lecturers construct classroom-based reading assessments. Three English lecturers were selected as the respondents of this research. The data were obtained through classroom observation and interview. Then, they were analyzed and reported descriptively. The results of this research revealed that in assessing reading comprehension all respondents used various techniques such as short answer question, matching test, multiple choice and observation (teacher made method) and summary and retelling (students conducted method). In addition, they used the different sources in designing assessment instruments. The sources were taken not only from textbook but also from internet, journals and other textbooks.
\end{abstract}

Keywords: English lecturers, Classroom-Based Reading Assessments, Reading Comprehension

\section{A. INTRODUCTION}

Assessment is regarded as the most important part of instruction. As stated by Rixon (1992, in Devianty, 2007) that the success of a learning program as commonly determined by the result of assessment.Generally, the teacher uses the tests as the best tool to measure their learners' ability in reading. However, the high score achieved by the learners in comprehending reading texts through formal tests, for example, final examination does not mean to guarantee that the learners are very good in reading.

Traditional assessment measures reading comprehension only provide a general indication of how well a student understands the text, failing to provide information about how the students use cognitive and met cognitive process or sufficiently explain why a student may be struggling (Klingner, 2004). According to Gottlieb (2006), classroom-based assessment or informal assessment have more power to evaluate the instruction and identify students' personal needs (Resnick and Resnick, 1992). Therefore, to assess students' ability in reading we may not only use formal assessment that measure the product but we need also to use informal assessment or classroom-based assessments that measure the process of constructing meaning in written text.

Based on description above, this research aims to identify techniques that the lecturers use in assessing reading comprehension and to find the way English lecturers construct classroombased reading assessments. 


\section{B. LITERATURE REVIEW}

1. Reading Comprehension

Ahuja (2001 in Mohammad, 1999: 27) mentions that there are three levels of comprehension. The first level is literal comprehension. Comprehension of this level involves surface meanings. At this level, the students can be asked to find information and ideas that are explicitly stated in the text. The second level is interpretive or referential comprehension. At this level students go beyond what is said and read for deeper meanings. They must be able to read critically and analyze carefully what they have read. This level includes thinking process such as drawing conclusions, making generalizations and predicting outcomes. Finally, the third level of comprehension is critical reading whereby ideas and information are evaluated. At this level, the teacher can test students' ability to differentiate between fact and opinion, the ability to recognize persuasive statements, and the ability to judge the accuracy of the information given in the text.

Grabe (2002) added that the level of comprehension of the text is influenced by how successfully the readers (their preexisting knowledge of the text, their interest in it, their purpose of reading it, etc.) interact with the text (the text type, the vocabulary, the grammar, etc.), and that the reading process engages the readers a series of stages: pre-reading, whilereading, and post-reading. Therefore, comprehension depends on integrating new knowledge with a network of prior knowledge (Harris and Hodges, 1995: 227).

\section{Assessments for Reading Comprehension}

Assessment (testing) tools refer to a broad range of ways of determining if students can perform or have mastered an objective. There are three reasons for testing the students as proposed by Reiser and Dick (1996) such as assigning grades to the students, determining what the students kno in order to provide appropriate remediation, and identifying ineffective portion of the instruction. Thus, it can be used to provide data to teachers to improve their instruction.

However, Alderson (2000)argued that there is no best method for testing reading. Some common reading assessment measures include multiple-choice, written and oral recall, cloze, summary, sentence completion, short-answer, open-ended-question, true/false, matching activity, checklist, ordering, and fill-in-the-blank tests. Researchers declare that the outcome each individual assessment task provides a limited representation of reading comprehension (Alderson, 2000). Therefore, the best way to assess students' reading comprehension is to use a combination of different measures (Klingner, 2004).

Regarding to the importance of using various tests, Johnston (1983cited in Cohen 1994: 216) proposes a series of new directions in the assessment of reading comprehension. Thus, he recommended the following areas which could be assessed:1)Awareness and the use of cues in the text 2) perception of the author's plan 3) insights into the nature of the text, 3) strategies for retrieving the information after reading 4) Schemata selection, 6) cognitive monitoring skill, 7) the knowledge of summarization rules

\section{Classroom based Assessment}

According to O'neil (1992, cited in Defianty, 2007:16), classroom based assessment is defined as informal ways of assessing the students that emphasize on the formative assessments.Moreover, Hancock (1994, cited in Defianty, 2007:25) defines that classroom based assessment as an alternative to conventional way of monittoring students' language progress and performances. 
Classroom based assessment uses activities that reveal what the students do with the language, emphasizing their strengts instead of their weaknesses. Classroom based assessment instruments are not only designed and structured differently from traditional tests but also scored differently. Because classroom based assessment is performance based that the point of language learning is communication. As stated by Gottlieb (2006: 11) that classroom based assessment involves the documentation of students performance, that is planned, collected and interpreted by the teachers as part of the instructional cycle.

Therefore, it can be concluded that in relation to reading comprehension, classroom-based assessments have a greater ability to measure complex reading tasks in a contextualized setting and can provide ample information about the use of reading strategies and skills by students (García \& Pearson, 1994).

\section{Classroom based Reading Assessments Options}

Cheng, Roger and $\mathrm{Hu}$ (2004:370) mention three categories of methods in assessing reading. 1) Teacher- made method, 2) student-conducted method (summarizing, journal, peer assessment, read aloud, dictation, self assessment and portfolio). 3) non-teacher developed method (standardized reading test). Two of the three methods, teacher made method and students conducted method, are regarded as classroom based reading assessment. The description of each method will be given below.

\section{a. The teacher made method}

The method includes some techniques such as short answer, multiple choce, cloze, and observation.

\section{1) Multiple Choice}

Ur (1996: 38) states that multiple-choice questions as consisting “... of a stem and a number of options (usually four), from which the testee has to select the right one." According to Wolf (1993), multiple-choice questions are a common means of assessing learners' reading comprehension because the task is familiar to subjects and is easy for researchers to score. Alderson (2000: 211) argued that multiple-choice test items are so popular because they provide testers with the means to control test-takers' thought processes when responding; they "allow testers to control the range of possible answers." Even though it may be time-consuming to prepare a multiple-choice test, it is easy to mark, and to evaluate.

\section{2) Short Answer}

Weir (1990) pointed out that short-answer tests are extremely useful for testing reading comprehension. Alderson (2000 :227) lso adds that short-answer tests are seen as "a semi-objective alternative to multiple choice." Test-takers are supposed to answer a question briefly by drawing conclusions from the text, not merely by responding "yes" or "no." The testtakers may be required to infer meaning from the text before answering the question.

\section{3) Cloze Test}

Cloze tests have been widely used in language assessment, particularly for the assessment of reading skills in language tests, both in classroom and in standardized tests. Moreover, cloze tests have been shown, according to Oller (1973: 106) to be the best indicator of reading ability. It is believed that cloze tests are more efficient and reliable than reading comprehension test which use open-ended questions or short answers because they are easier to evaluate and do not, as in many reading comprehension tests, depend on long written answers to evaluate.

The aim of cloze tests is to evaluate readability and reading comprehension (Heaton, 1991). Furthermore, cloze procedure is also used to assess reading strategies used by readers or to develop learners' reading strategies. Because some words are deleted, cloze forces 
readers to be more aware of the meaning and calls for the use of reading skills like scanning and searching that are often neglected in second language reading (Steinman, 2002:291).

\section{4) Observation}

Observation is the most common form of classroom based reading assessment. There are different ways to conduct observation. One way is to use an observation checklist, noting which reading behavior are observed. Another ways is to keep anecdotal records (Gunning, 2002 cited in Klingner, 2004).Anecdotal records not only includes the information about students reading comprehension but also the time, date setting and name of those involved.

\section{b. Student-conducted Method}

Students conducted method is the method that the students select and direct their own learning activities in doing reading assessment. The method includes some techniques such as summarizing, free recall test and retelling.

\section{1) Summarizing}

According Carson (1993), summarizing is an academic literacy task that entails both reading and writing abilities. Summary writing is commonly regarded as a reading comprehension strategy (Brown, Campione, \& Day, 1981; Redmann, 2005). As stated by Redmann (2005) that by completing a summary, students may become very proficient in distilling the main events from the text while actively using in context some of the key words they encounter within it. In addition, Trites and Mc Groarty (2005), asking students to write summary after reading can accurately evaluate students reading ability.

\section{2) Free Recall Test}

In free recall test, the students are required to read the text and then to write down everything to they can remember from the text. This technique is cosidered to provide a picture of learner process.

\section{3) Retelling}

Stoicovy (1994, cited in Wahyuni, 2007: 430) defines retelling as a post reading or post listening recalls in which readers or listeners tell what they remember orally or writenly. Thus, retelling is included to one of post reading activities. The importance of post reading activities cannot be denied, for at least three reading principles mentioned by Harmer (2007: 101-102) which can be found in post-reading activities, namely: students needs to be engaged with what they are reading, students should be encouraged to respond to the content of the text, and student should be exploited to the reading texts to the full. In short, the main point of using post reading activities is variety, which leads to creating positive, creative, innovative, effective and fun activities.

\section{RESEARCH METHODOLOGY \\ 1. Research Design}

The present study is qualitative in nature. By qualitative research, the data gained will be analyzed in a descriptive ways to explore their attitudes, behavior and experience (Dawson, 2009). It concerns a detailed description of situation. The data are collected in natural setting without being manipulated. The data focuses on the process, and the participants' point of view is essential. A qualitative case 38 
Apsari \& Haryudin : The analysis of...

study design was also employed in this research. This study was chosen because it allows the researcher to investigate a phenomenon in a single case (Nunan, 2000). That is to identify techniques that the lecturers use in assessing reading comprehension and to find the way English lecturers construct classroom-based reading assessments.

\section{Research Site and Participants}

This study was carried out in STKIP Siliwangi Bandung. This research site was basically chosen because it was open to researchers who wish to conduct the research. Thus, the researchers got easy access to carry out he research there that it could increase the feasibility of the research. Three English lecturers who are teaching reading for academic purposes subject were chosen as the participants of the study. It is necessary to find out whether or not there are differences in the teaching of reading including teaching techniques and the way they construct classroom-based reading assessments.

\section{Data Collection and Data Analysis}

Data was collected by observations, interviews, and document analysis. The researcher collected data by completing three observations at different times in each teacher's classroom. The lessons observed were reading lessons. During observations, the researcher was an observer and did not take part in any classroom activity. Field notes on the teacher's use of reading assessments were taken during each observation. After all the observations with a teacher were completed, the researcher shared the observation notes and interpretations with the teacher to check if the researcher's interpretation about the classroom activities were accurate. One purpose of the interview was to clarify the researcher's initial interpretation of the information collected during the observation(s). Most of the interviews lasted 40-50 minutes; a few took a little longer. The interviews were semi-structured. The interview was conducted in order to investigate the English lecturers' understanding of classroom-based assessment and the way they construct classroom-based reading assessments. The individual interviews were guided by an individualized set of questions about classroom-based reading assessment based on the class observations. Each interview was audiotape- recorded and transcribed. After each interview, the transcript and interview summary were sent to the teacher to check for agreement with the researcher's interpretations (member check). The documents collected included materials related to samples of materials teachers used in their classroom for the purpose of reading assessment such as worksheets, books, and paper and pencil tests.

Then the data colllected will be analyzed and reported descriptively.

\section{FINDINGS AND DISCUSSION}

This chapter discusses data analysis and and research finding based on data collection used in this research such as observation and interview. As it has been mentioned in the first chapter that this study aims at investigating how the classroom based reading assessment is implemented in the classroom.

\section{Teaching Learning Process}

Assessment is a part of the instruction. According to Sweet (2005), a good aseessment is actually embedded in the process of instruction. This means that observation is required in order to investigate how the assessment is conducted. The data from observation revealed that each respondents teach Reading for Academic Purposes. In each class, reading is taught once a week. All respondents used the similar textbook as the source of the material. All the chapter in the textbook discusses about the reading strategy such as skimming, scanning, previewing, predicting, etc. In the last chapter tells about reading for reserach. This subject aims that at the end of the semester the students can master all reading strategies that can help them to face in writing paper. 
Although all respondents used the same textbook in teaching reading, but they taught in different way. From the observation, it is revealed that only R\#2 who focused on the practices provided in the textbook. Doing some exercises through the tasks in the textbook was done to assess whether the students have understood things related to the text. It seemed that the respondents taught and assessed reading in the classroom based on the textbook.

R\#1 and R\#2 delivered the material partially in English and Indonesia. While, R\#3 mostly explained the lesson in English. She used various techniques in each meeting and employed the interesting games in pre activity. All the task given must be completed in colaborative learning. In addition, R\#1 and R\#3 took the tasks for the asessment from the other sources such as from internet, journals and other textbooks. It can be concluded that R\#1 and R\#3 taught reading skill based on the materials provided in the textbook but selected reading text for assessing students reading comprehension from the other sources. Data from interview revealed that the task from the textbook is not suitable for the students.

At the time of the observation, firstly, all respondents informing the objective to the students in opening the activity. Then, gave some exercises to students after teaching one topic. Having students do some exercises is one of the reading assessments. This indicates that the assessment is conducted in each meeting. It is in line with the statement of Klinger (2004) that comprehension should be assessed frequently, overtime, as a way of track in the students' growth and provide usefull information that can guide instructional decision making.

In the first observation to all respondents, they taught scanning skill. The topic of the lesson was the structure of the textbook. At the end of the activity they asked the students to find specific information related to the textbook content. In the second observation, topic of the lesson was characteristics of journal. All the respondents conducted different assessment. R\#1 gave one journal about coursebook analysis. Then, divided the students into groups and asked them to analyzed it. R\#2 asked the students to find out journal by themselves. Thus, each students took different journals and they must comprehend the journal. Then, one by one presented the content of the journal. While, R\#3 asked the students to find main idea of each paragraph taken from another sources.

From the data from observation indicated that the tasks for the asessment were not only taken from the textbook but also from the other sources such as from internet, journals and other textbooks. Then, the assessments were conducted not only after teaching one topic but also in mid test and final test. .

\section{The Techniques employed by the Lecturers}

Regarding to techniques used by the teachers, this study investigates three aspects such as 1) what techniques the respondents employed, 2) which techniques the respondents more frequently used, 3) the reason why the respondents more frequently used the techniques. The data were gathered through observation and interview. According to Cheng, Rogers and $\mathrm{Hu}$ (2004), there are two method in assessing reading comprehension: teacher-made method and student-conducted method. The teacher made method consist of quick answers, matching, interpretive, true false, multiple choice, cloze test, editting, completion of forms, observation, interview and questionnaire. The student-conducted method consist of summarizing, journal, peer assessment, dictation, self assessment, free recall test, retelling, gap summary, and portfolio.

The data from observation showed that in assessing reading assessment all respondents generally used three kinds of classroom-based reading assessments. The first was teacher made method, which includes short answer question, matching test, multiple choice and observation. The second was the students conducted method which involved summary and retelling. This indicates that the respondents used more than one techniques in reading 
assessment. It is in line with the statement of Klingner (2004) that the best way to assess students' reading comprehension is to use a combination of different measures. As stated by Anderson, Bachman, Perkins, and Cohen (1991, p. 61) that "more than one source of data needs to be used in determining the success of reading comprehension test items."

In addition, the data from interview revealed that R\#1 and R\#3 most frequently used the same techniques such as short answer questions, matching test and retelling. While, R\#2 most frequently used different techniques such as short answer questions and multiple choice.

The respondents' reasons of using those techniques can be seen in the following excerpt:

Because by using short answer questions, matching test and retelling the teacher can measure students' reading comprehension.

(R\#3) (Interview, translated version)

In addition, R\#2 stated the benefits of the techniques she frequently used in the classroom, as can be seen in the excerpt below.

Because those techniques not only useful to know whether the students can understand the text or not but also they are easy to exemine the result.

(R\#2) (Interview, translated version)

The above excerpt showed that Classroom-based assessments allow teachers to monitor students' development day by day (Darling- Hammond \& Goodwin, 1993; Resnick \& Resnick, 1992; Wiggins, 1992). Data from observation also revealed that there are various skill assessed in reading assessment. The reading skills are closely related to levels of comprehension. According to Ahuja (2001 cited in Mohammad, 1999), there are three levels of comprehension: literal, interpretive comprehension and critical comprehension.

From the observation, it was found that all the respondents assessed all three levels of comprehension. Related to literal level of comprehension, it was found that all respondents did the assessment on the identification of implicit and explicit information. Because there was no assessment related to translating the sentences. In the second observation, all respondents did the assessment related to the finding main ideas. It belongs to interpretive comprehension. And at four observation, the topic of the lesson is about reading graphic. R\#2 asked the students to find the text and make a graphic based on the text. While, R\#3 asked the students to match graphic to the text given. This indicates that the respondents had given assessment related to drawing conclusion and it belongs to interpretive comprehension. Finally, at the last observation, R\#3 gave the task to the students to differentiate between fact and opinion. This assessment belongs to critical comprehension.

Based on the findings above, therefore it can be concluded that all respondents assessed various skill such as 1)identification implicit and explicit information, 2) finding main ideas 3) drawing conclusion, 4) the ability to differentiate between fact and opinion. The findings showed that in relation to reading comprehension, classroom-based assessments have a greater ability to measure complex reading tasks in a contextualized setting and can provide ample information about the use of reading strategies and skills by students (García \& Pearson, 1994).

\section{The Way the Lecturers Construct the Assessments}

The way the respondents construct Classroom based reading assessment can be seen from the sources used by the respondents in designing assessments and the way of the respondents designed the assessment . The data were obtained through observation, interview and document analysis. 
The data from interview revealed that the repondents used the different sources in designing assessment instruments. It can be seen from the following excerpt.

Most of the asssessment instruments were taken from the textbook.

(R\#2) (Interview, translated version)

The finding above is supported from the observation data. From the observation, it is revealed that only R\#2 who focused on the practices provided in the textbook. R\#2 taught and assessed reading in the classroom based on the textbook. While, R\#1 and R\#3 said that they took the other sources in designing assessment instruments such as from internet and other sources. It can be seen from the following excerpt.

All the tasks I gave to students were taken from the other sources which is appropriate with the teaching material. I did not take the assessment instruments from the textbook because the topic of the reading material is not suitable for the students.

(R\#3) (Interview, translated version)

This finding is supported from observation data that that R\#1 and R\#3 taught reading skill based on the materials provided in the textbook but selected reading text for assessing students reading comprehension from the other sources. This indicates that there were other efforts to design different tasks in assessing students' reading comprehension.It is in line with Harmer's (2001: 213) statement that teacher needs to work to create interest in the topic and tasks in order to get the students read enthusiastically in class.

\section{E. CONCLUSION}

Assessment is regarded as the most important part of instruction. As stated by Rixon (1992, in Devianty, 2007) that the success of a learning program as commonly determined by the result of assessment.Generally, the teacher uses the tests as the best tool to measure their learners' ability in reading. However, the high score achieved by the learners in comprehending reading texts through formal tests, for example, final examination does not mean to guarantee that the learners are very good in reading. As argued by Alderson (2000) that there is no best method for testing reading. This indicates that the best way to assess students' reading comprehension is to use a combination of different measures (Klingner, 2004). Therefore, to assess students' ability in reading we may not only use formal assessment that measure the product but we need also to use informal assessment or classroom-based assessments that measure the process of constructing meaning in written text.

Accordingly, this research aims to identify techniques that the lecturers use in assessing reading comprehension and to find the way English lecturers construct classroom-based reading assessments. Based on research result, several conclusions from the findings are drawn as follows.

Firstly, regarding to techniques used by the teachers, the data from observation and interview showed that in assessing reading comprehension all respondents used various techniques such as short answer question, matching test, multiple choice and observation (teacher made method) and summary and retelling (students conducted method).

The last, the result concerning the way the lecturers construct the assessments. The finding revealed that the repondents used the different sources in designing assessment instruments. Most of the asssessment instruments used by R\#2 were taken from the textbook. The finding above is supported from the observation data. From the observation, it is revealed that only R\#2 42 
who focused on the practices provided in the textbook. R\#2 taught and assessed reading in the classroom based on the textbook. While, R\#1 and R\#3 took the other sources in designing assessment instruments such as from internet, journals and other textbooks. They taught reading skill based on the materials provided in the textbook but selected reading text for assessing students reading comprehension from the other sources.

\section{F. REFERENCES}

Alderson, J. Charles. (2000). Assessing Reading. Australia: Cambridge University Press.

Brown, A. L., Campione, J. C. \& Day, J. D. (1981). Learning to Learn: on Training Students to Learn From Texts. Educational Researcher, 10(2).

Brown, H. Douglas. 2001. Teaching by Principle: An Interactive Approach to Language Pedagogy (Second Edition). NewYork: Pearson Education Company.

Carson, J. G. (1993). Reading for writing: Cognitive perspectives. In Carson, J. G., \& Leki, I. (Eds.), Reading in the composition classroom: Second language perspectives. Boston: Heinle and Heinle Publishers.

Cohen, D. Andrew. (1996). Assessing Language Ability in the Classroom. 2nd Edition. U.S.A:

Heinle \& Heinle Publisher

Cheng, Rogers and Hu. (2004). ESL/EFL Instructors' Classroom Assessment Practice: Purposes, Methods, Procedures. Queen's University and University of Alberta. Available online: http://ltj.sagepub.com

Darling-Hammond, L., \& Goodwin, L. (1993). Progress Toward Professionalism In Teaching.

In G. Kawelti (Ed.), Challenges and achievements of American education (pp. 1952). Alexandria, VA: Association for Supervision and Curriculum Development.

Dawson, C. (2009). Introduction to Research Methods. Oxford: How to Books.

Defianty. (2007). Language Assessment fr Young Learner. Paper Presented atthe 55th TEFLIN

International Conference. Jakarta: UIN Syarif Hidayatullah

García, G. E., \& Pearson, P. D. (1994). Assessment and Diversity. Review of Research in Education, 20, 337-392.

Gottlieb. (2006). Assessing English Language Learner: Bridge from Language Proficiency to Academic Achievement. California: Corwin Press.

Grabe, W. (2002). Second Language Reading. In: The Oxford Handbook of Applied Linguistics. Kaplan, R.B. (ed.). OxfordUniversity Press, Oxford, p. 49-59.

Harmer, J. (2001). The Practice of English Language Teaching. England: Longman. Harmer, J. (2007). How to Teach English. Essex, UK: Pearson-Longman.

Harris, T. L., \& Hodges, R. E. (1995). The Literacy Dictionary: The Vocabulary of Reading and Writing. Newark, DE: International Reading Association.

Heaton, J. B. 1991. Writing English Language Tests. New York: Longman.

Klingner. 2004. Assessing Reading Comprehension. Available on line:http//aei.sagepub.com /cgi /content/abstract/29/4/59//.

Oller, J.R.. (1986). Language Tests in School. London : Longman.

McNeil, J. D. (1992). Reading Comprehension New Directions for Classroom Practice $\left(3^{\text {rd }}\right.$ ed.). Los Angeles, CA: University of California. 
Mohammad, A. (1999). What do We Test When Test Reading Comprehension?Available online http://iteslj.org/techniques/mohammad-testing Reading-html.

Redmann, J. (2005). An Interactive Reading Journal for All Levels of the Foreign Language Curriculum. [on line] available: http://www.actfl.org/i4a/pages/Index.cfm?pageID=4628

Resnick, L. B., \& Resnick, D. P. (1992). Assessing The Thinking Curriculum: New Tools For Educational Reform. In B. R. Gifford \& M.C. O'Connor (Eds.), Changing assessment:

Alternative views of aptitude, achievement, and instruction (pp. 37-75). Boston: Kluwer Academic Publishers.

Shepard, L. A. (1995). Using assessment to improve learning. Educational Leadership, 52(5), $38-43$.

Steinman, L. (2002). A Touch of ... Class!: Considering the Cloze. [Electronic]. The Canadian

Modern Language Review. Vol.59.2: 291-302. Available: EBSCO Host: Academic Search Premier. [Accessed on 2017, March 28].

Trites, L and Mc. Groarty, M. (2005). Reading to Learn and Reading to Integrate: New Tasks for Reading Comprehension Tests? Language Testing, 22(2), 174-210.

Ur, P. (1996). A Course In Language Teaching: Practice \& Theory. Cambridge: Cambridge University Press.

Wahyuni, Sri. (2007). Reading Comprehension Assessment through Retelling Different types of Text. Paper Presented at the 55th TEFLIN International Conference. Jakarta UIN Syarif Hidayatullah.

Wiggins, G. P. (1992). Assessing Student Performance. San Francisco: Jossey-Bass.

Wolf, D. (1993). A Comparison of Assessment Tasks Used to Measure FL Reading Comprehension. Modern Language Journal, 77, 473-89. 